\title{
The Mediating Role of Self-efficacy and Hope on Primary School Students' Social-emotional Learning and Primary Mental Abilities
}

\author{
Müge Yüksel $^{1, *}$, Nesrullah Okan ${ }^{1}$, Zehra Eminoğlu ${ }^{2}$, Dilek Akça-Koca ${ }^{3}$ \\ ${ }^{1}$ Department of Educational Sciences, Marmara University, Turkey \\ ${ }^{2}$ Bahcelievler Guidance and Research Center, Marmara University, Turkey \\ ${ }^{3}$ Institute of Educational Sciences, Marmara University, Turkey
}

Copyright $\bigcirc 2019$ by authors, all rights reserved. Authors agree that this article remains permanently open access under the terms of the Creative Commons Attribution License 4.0 International License

\begin{abstract}
The purpose of this research is to determine the mediating role of self-efficacy and hope on the relationship of individuals' scores on the Primary Mental Abilities (PMAs) Test 7-11 with social emotional learning. In addition, the relationship of PMAs scores with hope and self-efficacy have also been examined. The study has been carried out over 281 fourth-grade students (160 female and 121 male). For data collection, the PMAs Test 7-11 was first applied to the students. Students with PMAs Test 7-11 scores also filled in the Self-efficacy Scale for Children, the Social-emotional Learning Scale, and the Children's Hope Scale. As a result of the analysis, a positive, significant correlation was found among all the variables. Moreover, a partially mediating role was found for hope and self-efficacy on the relationship between ability level and social emotional learning. This research is believed able to contribute to studies related to talented students.
\end{abstract}

Keywords PMAs Test 7-11, Social Emotional Learning, Hope, Self-efficacy

\section{Introduction}

Individuals are expected to possess varying capacities of intelligence and ability for adapting to life, for performing certain ways, and for being successful. At the same time, individuals' emotional intelligence is emphasized as contributing to their academic success, both in school achievement and in the process of adapting to social life (Parker, Summerfeldt, Hogan, \& Majeski, 2004). Intelligence is an important factor in individual life and has been defined by Gardner (1987) as the ability to solve a problem or shape a product in different cultural settings. Intelligence has been defined by Yörükoğlu (1983) as the composition of talents emerging in the harmonious process of the various abilities contained in the functions of the mind, such as perception, memory, thinking, and learning.

Using emotional intelligence as social intelligence, Goleman (1998) stated emotional intelligence to come from elements such as self-consciousness, emotion management, self-direction, empathy, and social relations. At the same time, he argued social intelligence to come from two parts: social awareness and social skills. Social skills, which can be defined as communicating; understanding emotions in interpersonal relationships, the thinking and behaviors of others, and being able to behave in accordance with these; complying with one's environment; making friends; showing socially acceptable behaviors; expressing one's self; and coping with problem situations (Gresham \& Elliott, 1990; Guerrero \& Jones, 2003; Marlowe, 1986), can support learning and school life in important ways. Students learn not only on their own but also in the social environment where their friends and family are involved, particularly in collaborations with their teachers (Zins, Bloodworth, Weissberg, \& Walberg, 2004). The study by Graziano, Reavis, Keane, and Calkins (2007) examined the effects of social adjustment and emotional regulation on children's academic success. Children's academic achievement (math results, literacy, classroom productivity) were found to be positively affected by emotion regulation skills. In addition, thanks to social adjustment and emotional adjustment skills, the components important in academic achievement and motivation have improved, such as developing student-teacher relationships and independent learning behaviors.

According to Renzulli (1986), superior intelligence is defined by the intersection of the clusters of above-average generic and special ability levels, higher motivation levels, and higher creativity levels. Above-average general and 
special abilities include abilities such as high-level abstract thinking, high memory capacity, speedy information processing, and the ability to adapt to newly encountered situations. Features included in creativity, the second set, are abilities such as fondness for detail, original ideas, and being able to be receptive to innovation and change. The third set, noted as non-mental characteristics in the scope of high motivation levels, can be considered as abilities such as being work- or problem-oriented, being able to work with determination and loyalty, having self-confidence, being void of feelings of inferiority, and setting high standards for one's goals.

Meeting the emotional needs of gifted children is essential for their healthy socio-emotional development. Having the sense to struggle with the challenges they face in their emotional worlds will give them an advantage regarding their self-esteem, positive self-perception, and social relationships, thus enabling them to fully use their potential (Silverman, 1993). In this regard, examining research is necessary on how individuals with high-level talents may feel about their empowerment, how they perceive themselves, how they view their qualifications, and the emotional reflections of their experiences in their social environment. Webb (1994) stated that due to their mental development and motor development not being synchronized, gifted children's inability to draw what they imagine in their minds may result in emotional blasts. At the same time, he pointed out that these children are highly perfectionist and have unrealistically high expectations from themselves. A qualitative study by Ford (1989) was conducted on 57 students with high levels of talent or potency. As a result of the interviews with these students, Ford drew the opinion that these students are confused because of their talents, get bored at school, and get in trouble because of the expectations from their families and teachers. According to the research conducted by Arslan (2016) with the participation of gifted children attending third and fourth grades, on the other hand, gifted students' self-concept scores were found to be higher than children with normal ability levels. At the same time, gifted children were found to have significantly higher levels of social competence, interpersonal skills, self-control skills, and academic skills than children with normal ability levels.

Various studies exist showing the relationship among academic achievement, self-efficacy, social-emotional learning, and hope levels in the field. For example, Salanova, Martinez, and Lorens (2012) argued self-efficacy to have a positive effect on future achievements when associated with internal excesses, but to have a negative effect on future academic achievement when linked to external excesses. In addition, Sarıer (2016) and Aydin (2010) found in their study of the factors affecting students' academic achievement that self-efficacy is among the most important factors affecting students' academic success. Carpenter (2007) compared the relationships among students' academic achievement, self-efficacy, and motivational orientation in a meta-analysis study involving different levels of education. As a result of the study, he determined a strong relationship to exist between students' academic achievement and self-efficacy regardless of education level. Studies are found showing a positive relationship to exist between hope levels and academic achievement. For example, according to Moulden and Marshall (2005), those with high hope levels build realistic goals and make realistic plans, relying on their skills to achieve these goals. In a qualitative study carried out by Tarhan and Bacanlı (2016), emotional and cognitive items were observed to be emphasized while defining the concept of hope; hope includes future positive expectations and adds meaning to life. Setting goals that are likely to occur is important.

Families in Turkey are more concerned with their children's academic success than a successful personal or social life. As a proof for this, most parents from the primary school period onward focus on the transition from elementary school to high school and then to the university preparatory process without investigating whether their children have abilities in the field of music, painting, sports, and so on. However, individuals who continue to explore and develop their talents in these areas may become more successful academically. According to the research results, individuals with advanced socio-emotional and emotional intelligence can be said to have high academic achievement (Durlak, Weissberg, Dynmick, Taylor, \& Schellinger, 2011; Marquez, Martin, \& Brackett, 2006; Parker, Summerfeldt, Hogan, \& Majeski, 2004) but not all individuals with high academic skills can be said to have high compliance or social adaptability (O'Connor \& Litte, 2003). Aside from having the instinct for success, developing positive relationships with peers and adults, adapting to growth and development, taking responsibility for one's decisions, and having hope in the future are also crucial for children. In fact, all these skills also positively affect success levels. For this reason, individuals with high self-efficacy, socio-emotional well-being, adaptability, and high levels of hope are more comfortable adapting to academic life and may be able to lead a more functional life in the future. When we looked at the research, we found no study on the combined levels of talent, self-efficacy, social emotional learning, and hope during the primary school period, which is the basis of academic life. The levels of competence, social emotional learning, and hope felt by one at the end of childhood (Yavuzer, 2011) when self-perception is just developing may be a good predictor of ability level. This study also expects to support the work in the field of guidance and psychological counseling in Turkey, especially in the context of educational and personal guidance. Thanks to these kinds of studies, children with high skill levels can have more harmonious lifestyles.

As a result, the aim of this study is to investigate the relationship between primary school students' ability 
levels and their levels of self-efficacy, social-emotional learning and hope.

For this purpose, answers to the following questions are sought:

1. Do primary school students' levels of talent, self-efficacy, social-emotional learning, and hope differ according to certain variables (gender, parents' educational status and socio-economic level)?

2. What is the relationship between primary school students' ability levels and their levels of self-efficacy, social-emotional learning, and hope?

3. Do self-efficacy and hope have any role in the relationship between primary school students' levels of ability and social-emotional learning?

\section{Method}

\subsection{Study Group}

The study group consists of fourth-grade elementary school students within the scope of Providing Educational Support for Gifted/Special Talented Children: Enhancing Social Awareness and Sensibility, a project supported by the Istanbul Development Agency and conducted by the Bahçelievler Guidance and Research Center under the Bahçelievler Governorship. The Primary Mental Abilities (PMAs) Test 7-11 has been applied to all primary school students (24 primary schools) in the Bahçelievler district within the scope of the project. These primary schools have a total of 5,000 fourth-grade students.

In this study, 281 students were randomly selected from six primary schools also randomly selected among the 24 where the PMAs Test 7-11 had been applied. These randomly selected students are in the group of high-level ability, mid-level ability, and low level ability students. The Self-Efficacy Scale for Children, the SocialEmotional Learning Scale, and the Children's Hope Scale have been applied to these 281 fourth-grade students. Information on these students is presented in Table 1.

Table 1. Demographic Information of the Survey Participants

\begin{tabular}{|c|c|c|c|}
\hline Tables & Groups & $f$ & $\%$ \\
\hline \multirow[t]{3}{*}{ Gender } & Female & 160 & 56.9 \\
\hline & Male & 121 & 43.1 \\
\hline & Total & 281 & 100.0 \\
\hline \multirow[t]{7}{*}{ PMAs Test 7-11 Results } & Low & 94 & 33.5 \\
\hline & Middle & 102 & 36.3 \\
\hline & High & 85 & 30.2 \\
\hline & Total & 281 & 100.0 \\
\hline & Illiterate & 6 & 2.1 \\
\hline & Literate & 23 & 8.2 \\
\hline & Primary education & 66 & 23.5 \\
\hline \multirow[t]{7}{*}{ Father's Education } & High school & 106 & 37.7 \\
\hline & University Degree & 73 & 26.0 \\
\hline & Master's & 7 & 2.5 \\
\hline & Total & 281 & 100.0 \\
\hline & Illiterate & 10 & 3.6 \\
\hline & Literate & 18 & 6.4 \\
\hline & Primary education & 87 & 31.0 \\
\hline \multirow[t]{4}{*}{ Mother's Education } & High school & 95 & 33.8 \\
\hline & University Degree & 61 & 21.7 \\
\hline & Master's & 10 & 3.6 \\
\hline & Total & 281 & 100.0 \\
\hline \multirow[t]{4}{*}{ Socioeconomic Status } & Lower & 47 & 16.7 \\
\hline & Middle & 145 & 51.6 \\
\hline & Upper & 89 & 31.7 \\
\hline & Total & 281 & 100.0 \\
\hline
\end{tabular}


Demographic information is seen in Table 1, 160 students $(56.9 \%)$ from the sample group are female and $121(43.1 \%)$ are male; 94 (33.5\%) of the student participants who had taken the TKT test do not have low ability levels, 102 (36.3\%) have mid-ability levels, and 85 $(30.2 \%)$ have high ability levels. When looking at the participating students' father's educational status, six fathers $(2.1 \%)$ were found to be illiterate, $23(8.2 \%)$ to be literate, $66(23.5 \%)$ to have primary education, 106 to have a high school education (37.7\%), 73 (26\%) to have a university degree, and seven (2.5\%) to have their Master's degree. According to mother's educational status, $10(3.6 \%)$ mothers are illiterate, 18 (6.4\%) are literate, 87 (31\%) have a primary education, $95(33.8 \%)$ have a high school diploma, $61(21.7 \%)$ have a university degree, and 10 (3.6\%) have a Master's degree. When examining the sampled group in terms of socioeconomic status, 47 $(16.7 \%)$ students are in the low-income group, $145(51.6 \%)$ are in the middle-income group, and $89(31.7 \%)$ are in the high-income group.

\subsection{Data Collection Tools}

Primary Mental Abilities (PMAs) Test 7-11. This scale was applied by Enterprise (2005) to 7- to 11-year-olds to measure general mental ability and gives four special talent scores. It has a total of 122 items and sub-items, the four main items being language ability, spatial ability, discrimination ability, and numerical ability. Language proficiency has three subtests: words (30 items), pictures (15 items), and word groups (21 items). Spatial ability has 10 items. Discrimination ability has 15 items. Lastly, numerical ability has 31 items; $76.95 \%$ of the total variance of the scale is explained according to structural validity (At1lgan, 2005).

Self-Efficacy Scale for Children. The scale, adapted to Turkish by Waste and Karaca (2012) and applied to adolescents, is a 5-point Likert-type scale (1 being "none" and 5 being "very good"). It has 3 sub-dimensions: academic self-efficacy, social self-efficacy, and emotional self-efficacy. The self-efficacy level increases as the score obtained from the scale increases. According to the construct validity, the scale explained $43.74 \%$ of the total variance.

Total scores for the scale can range from 21 to 105, with higher scores indicating a higher self-efficacy level; $43.74 \%$ of the total variance of the scale is explained according to structural validity. The correlation between scores when examining test-retest reliability has been found as .88 . Cronbach's alpha of internal consistency and reliability is .86 for the entire scale (Akin, 2015, Waste \& Karaca, 2012).

Social-Emotional Learning Scale. The scale, adapted to Turkish by Arslan and Akin (2013) and applied to primary school students, is 5 -point Likert-type scale ( $1=$ "I disagree completely" and 5 = "I completely agree"). It has three sub-dimensions: task identification, peer relations, and self-regulation. Total scores from the scale can range from 20 to 100, with higher scores indicating higher levels of social-emotional learning. Correlations between scores show good fit in the confirmatory factor analysis, with test-retest reliability being found as .71. Cronbach's alpha of internal consistency/reliability is .90 for the entire scale (Akin, 2015, Arslan \& Akın, 2013).

Children's Hope Scale. The scale, adapted to Turkish by Atik and Kemer (2009) and applied to 8- to 16-year-old, is a 6-point Likert-type scale ( 1 = "Never"; 6 = "Always") with six items. The scale, which has a total of 6 items, has two sub-dimensions, namely the means to reach the goal and motivation. The total score is between 6-36. The higher the score, the higher the level of hope. According to the construct validity, the scale explained $58 \%$ of the total variance.

Total scores for the scale can range from 6 to 36, with higher scores indicating higher levels of hope and $58 \%$ of the total variance of the scale being explained according to structural validity. When examining the test-retest reliability, correlations between the scores were found to be .57. Cronbach's alpha of internal consistency/reliability is .74 for the entire scale (Akın, 2015, Atik \& Kemer, 2009).

\subsection{Operations}

Within the scope of the research, two separate operations were performed. In the first process, the Bahçelievler Guidance and Research Center examined the PMAs Test 7-11 that had been applied to primary school students from 24 schools. Six primary schools from this group were randomly selected, with 281 fourth-grade students without any disabilities enrolled in these schools in the high-, middle-, and low-ability level groups. In the second phase of the study, the Self-Efficacy Scale for Children, the Social Emotional Learning Scale, and the Children's Hope Scale were applied to these students. The data were then loaded into the package programs SPSS 22 and AMOS 20, analyzed, and then presented in tables.

\section{Results}

The findings of the research are arranged according to a specific sequence in the direction of the aims and have been tabulated in sequential order.

The primary aim of the research is to answer if primary school students' levels of ability, self-efficacy, social-emotional learning, and hope differ according to certain variables (gender, parental education status, and socio-economic level). The analyses related to explaining the answer to this question are given in Table 2. 
Table 2. Independent Groups t-Test for Determining How Scores from the PMAs Test 7-11, the Self-Efficacy Scale for Children, the Social-emotional Learning Scale, and Children's Hope Scale Differ According to the Variable of Gender

\begin{tabular}{|c|c|c|c|c|c|c|c|c|}
\hline \multirow{2}{*}{ Score } & \multirow{2}{*}{ Groups } & \multirow{2}{*}{$N$} & \multirow{2}{*}{$\bar{\chi}$} & \multirow{2}{*}{$S D$} & \multirow{2}{*}{$\mathrm{Sh}_{\overline{\mathrm{x}}}$} & \multicolumn{3}{|c|}{$t$-test } \\
\hline & & & & & & $t$ & $S D$ & $p$ \\
\hline \multirow{2}{*}{ PMAs } & Girl & 160 & 2.03 & .78 & .06 & \multirow{2}{*}{1.53} & \multirow{2}{*}{.096} & \multirow{2}{*}{.127} \\
\hline & Male & 121 & 1.88 & .80 & .07 & & & \\
\hline \multirow{2}{*}{ Self-efficacy } & Girl & 160 & 83.18 & 13.21 & 1.04 & \multirow{2}{*}{2.32} & \multirow{2}{*}{1.53} & \multirow{2}{*}{.021} \\
\hline & Male & 121 & 79.61 & 12.13 & 1.10 & & & \\
\hline \multirow{2}{*}{ Social-Emotional Learning } & Girl & 160 & 85.03 & 12.30 & .97 & \multirow{2}{*}{2.83} & \multirow{2}{*}{1.47} & \multirow{2}{*}{.005} \\
\hline & Male & 121 & 80.85 & 12.11 & 1.10 & & & \\
\hline \multirow{2}{*}{ Hope } & Girl & 160 & 31.16 & 4.51 & .35 & \multirow{2}{*}{3.38} & \multirow{2}{*}{.55} & \multirow{2}{*}{.001} \\
\hline & Male & 121 & 29.28 & 4.70 & .42 & & & \\
\hline
\end{tabular}

As shown in Table 2, a difference exists between the arithmetic averages for the groups in terms of the girls' $t$-test as regards the independent groups $t$-test for determining whether the sample group's PMAs scores show a significant difference according to gender, but this difference is not significant $(t=1.53 ; p<.127)$. On the other hand, the scores for social-emotional learning $(t=$ $2.83 ; p<.005)$ and hope $(t=3.38 ; p<.05)$ show the difference between the arithmetic means to be significant in favor of girls.

As mentioned in the first objective, no significant difference exists between parents' educational status and socioeconomic levels. As such, their results are not included here.

The second goal of the research is to determine the relationship of primary school students' levels of ability with their levels of self-efficacy, social-emotional learning, and hope. The analyses that are related to answering this question have been given in Tables 3 and 4 .

As shown in Table 3, the difference between groups' arithmetic means for determining whether the students who constitute the sample group have significant differences in PMAs Test 7-11 scores according to the variable of self-efficacy was found to be significant as a result of one-way ANOVA testing $(f=4.99, p<.05)$. Likewise, the differences between the arithmetic means of the groups were found meaningful as a result of the one-way ANOVA according to the variable of social-emotional learning $(f=$ $9.91 ; p<.000)$ and the variable of hope $(f=6.98 ; p<.001)$. After these operations, complementary analyses were carried out to determine which groups are the sources of the differences. When determining which post-hoc analysis to use for this purpose, the homogeneity of variances was first checked, and the variances were found to be homogeneous for all three variables $\left(L F_{1}=624, p_{1}>.05\right.$; $\left.L F_{2}=1.24 ; p_{2}>.05 ; L F_{3}=, 300 p_{3}<.05\right)$. For this reason, Scheffe's method, widely used when the variances are homogeneous, has been applied, and the results are presented in Table 4.

As shown in Table 4, the post-hoc Scheffe test shows middle-level students $(p<.05)$ and high-level students $(p$ $<.05)$ are seen to have lower self-efficacy than talented students as a result of the analysis. The arithmetic mean between the self-efficacy of mid- and high-ability students is not significant although it does seem to favor high-level talents $(p>.05)$. One-way ANOVA followed by the post-hoc Scheffe test was used to determine the subgroups of emotional learning scores that differed according to the TCI variable. As a result of the post-hoc Scheffe test, it is seen that the students with lower-level ability have lower emotional learning than the students with middle-level ability $(\mathrm{p}<01)$ and students with high-level ability students $(p<01)$. The same distinction is seen in favor of high-level talented students for social-emotional learning in mid- and high-level talented students $(p<.05)$. One-way ANOVA, used for determining how subgroups' hope scores differ according to the PMAs, revealed in the post-hoc Scheffe test results that low-level gifted students have lower hope scores than mid- $(p<.01)$ and upper-level $(p<.01)$ gifted students. The arithmetic average between the hope scores of mid- and high-level talented students is not significant, although it seems to favor high-level talented students $(p>.05)$. 
Table 3. One-way Analysis of Variance (ANOVA) Test Results for Determining Whether Students' PMAs Test 7-11 Scores Differ According to Their Scores for Self-Efficacy, Social-emotional Learning, and Hope

\begin{tabular}{|c|c|c|c|c|c|c|c|c|c|c|}
\hline Score & Group & $n$ & $\bar{\chi}$ & $S D$ & $\operatorname{Var}(\mathbf{K})$ & $K T$ & $S D$ & $\mathrm{~K}-\mathrm{O}$ & $f$ & $p$ \\
\hline \multirow{4}{*}{ Self-Proficiency } & Lower & 94 & 78.47 & 1.33 & $\mathbf{b} / \mathbf{n} G$ & 55.34 & 2 & 804.29 & \multirow{4}{*}{4.99} & \multirow{4}{*}{.007} \\
\hline & Middle & 102 & 82.33 & 1.19 & inside $G$ & $1,534.09$ & 270 & 160.91 & & \\
\hline & High & 85 & 84.34 & 1.42 & Total & $1,553.24$ & 280 & & & \\
\hline & Total & 281 & 81.65 & .76 & & & & & & \\
\hline \multirow{4}{*}{ Emotional Learning } & Lower & 94 & 79.2447 & 1.32904 & $\mathbf{b} / \mathbf{n} G$ & 8.87 & 2 & $1,427.20$ & \multirow{4}{*}{9.91} & \multirow{4}{*}{.000} \\
\hline & Middle & 102 & 83.5980 & 1.24259 & inside $G$ & $2,845.54$ & 270 & 143.94 & & \\
\hline & High & 85 & 87.2118 & 1.10183 & Total & $2,833.30$ & 280 & & & \\
\hline & Total & 281 & 83.2349 & .73815 & & & & & & \\
\hline \multirow{4}{*}{ Hope } & Lower & 94 & 28.94 & .52 & $\mathbf{b} / \mathbf{n} G$ & 4.539 & 2 & 146.72 & \multirow{4}{*}{6.98} & \multirow{4}{*}{.001} \\
\hline & Middle & 102 & 30.82 & .43 & inside $G$ & 777.655 & 270 & 21.01 & & \\
\hline & High & 85 & 31.35 & .44 & Total & 782.194 & 280 & & & \\
\hline & Total & 281 & 30.35 & .72 & & & & & & \\
\hline
\end{tabular}

Table 4. The Post-Hoc Scheffe Test Results

\begin{tabular}{|c|c|c|c|c|c|}
\hline Self-Efficacy & PMA & PMA & $\bar{\chi}_{i}-\bar{\chi}_{j}$ & $S \boldsymbol{h}_{\boldsymbol{x}}$ & $p$ \\
\hline & Low & Mid & $-3.85^{*}$ & 1.81 & .034 \\
\hline & & High & $-5.86^{*}$ & 1.89 & .002 \\
\hline & Low & Mid & $3.85^{*}$ & 1.81 & .034 \\
\hline & & High & -2.00 & 1.86 & .282 \\
\hline & Low & Mid & $5.86^{*}$ & 1.89 & .002 \\
\hline & & High & 2.00 & 1.86 & .282 \\
\hline \multirow[t]{7}{*}{ Social-Emotional Learning } & PMA & PMA & $\bar{\chi}_{i}-\bar{\chi}_{j}$ & $S \boldsymbol{h}_{\boldsymbol{x}}$ & $p$ \\
\hline & Low & Mid & $-4.35^{*}$ & 1.71 & .012 \\
\hline & & High & $-7.96^{*}$ & 1.79 & .000 \\
\hline & Low & Middle & $4.35^{*}$ & 1.71 & .012 \\
\hline & & High & $-3.61^{*}$ & 1.76 & .041 \\
\hline & Low & Mid & $7.96^{*}$ & 1.79 & .000 \\
\hline & & High & $3.61^{*}$ & 1.76 & .041 \\
\hline \multirow[t]{7}{*}{ Hope } & PMA & PMA & $\bar{\chi}_{i}-\bar{\chi}_{j}$ & $S \boldsymbol{h}_{\boldsymbol{x}}$ & $p$ \\
\hline & Low & Mid & $-1.87^{*}$ & .65 & .005 \\
\hline & & High & $-2.40^{*}$ & .68 & .001 \\
\hline & Low & Mid & $1.87^{*}$ & .65 & .005 \\
\hline & & High & -0.52 & .67 & .432 \\
\hline & Low & Mid & $2.40^{*}$ & .68 & .001 \\
\hline & & High & .52 & .67 & .432 \\
\hline
\end{tabular}

The third objective of the research is to find whether the variables of self-efficacy and hope have any role in the relationship between elementary school students' ability and social emotional learning levels. The analyses for this are given in Tables 5 and 6.

The first step is to use correlation analysis in order to determine the relationships of the variables to each other. When examining the correlation analysis data presented in
Table 5, the total score for the PMAs Test 7-11 is seen positively and significantly correlated with the other three variables. In the same way, all the research variables are found to be in a meaningful relationship with each other. After these findings, the package program, AMOS 20, has been used to analyze the relationship between PMAs and social emotional learning in order to determine the mediator role of self-efficacy and hope. 
Table 5. Mean, Standard Deviation, and Correlation Values for the Variables $(\mathrm{n}=281)$

\begin{tabular}{ccccccc}
\hline Variables & $\bar{\chi}$ & $\boldsymbol{S D}$ & 1 & 2 & 3 & 4 \\
\hline PMAs & 90.87 & 1.17 & 1.00 & $.27^{* *}$ & $.20^{* *}$ & $.22^{* *}$ \\
\hline Social-emotional learning & 81.65 & .50 & & 1.00 & $.64^{* *}$ & $.68^{* *}$ \\
\hline Self-efficacy & 83.23 & .54 & & & 1.00 & $.61^{* *}$ \\
\hline Hope & 30.35 & .21 & & & 1.00 \\
\hline
\end{tabular}

$* * p<.001$

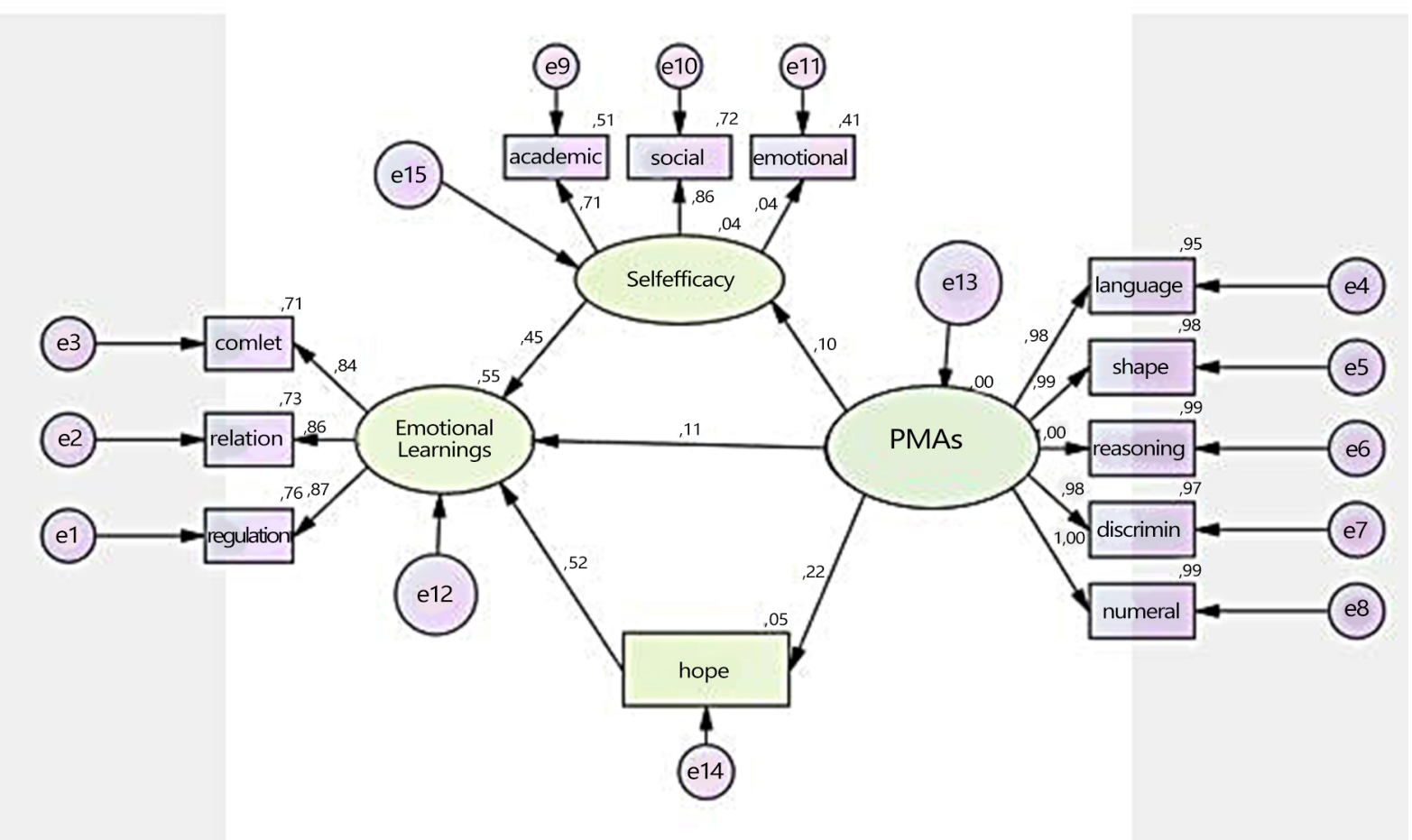

Figure 1. PMAs and social-emotional learning path analysis made to determine the instrumental role of the variables of hope and self-efficacy.

Table 6. Comparison of Standard Conformity Assessment Criteria and Research Results

\begin{tabular}{|c|c|c|c|}
\hline $\begin{array}{c}\text { Compliance } \\
\text { Measures }\end{array}$ & Good Harmony & Acceptable Compliance & $\begin{array}{l}\text { Compliance Values Obtained } \\
\text { in Research }\end{array}$ \\
\hline$P$ & $0.05 \leq \mathrm{p} \leq 1$ & $0.01 \leq \mathrm{p} \leq 0.05$ & 0.118 \\
\hline$\chi^{2} / d f$ & $0 \leq \chi^{2} / d f \leq 2$ & $2 \leq \chi^{2} / d f \leq 3$ & 1.25 \\
\hline RMSEA & $0 \leq R M S E A \leq 0.05$ & $0.05 \leq R M S E A \leq 0.08$ & 0.030 \\
\hline$S R M R$ & $0 \leq S R M R \leq 0.05$ & $0.05 \leq S R M R \leq 0.10$ & 0.01 \\
\hline$N F I$ & $0.95 \leq N F I \leq 1.00$ & $0.90 \leq N F I \leq 0.95$ & 0.989 \\
\hline$N N F I$ & $0.97 \leq N N F I \leq 1.00$ & $0.95 \leq N N F I \leq 0.97$ & 0.998 \\
\hline$C F I$ & $0.97 \leq C F I \leq 1.00$ & $0.95 \leq C F I \leq 0.97$ & 0.998 \\
\hline$G F I$ & $0.95 \leq G F I \leq 1.00$ & $0.90 \leq G F I \leq 0.95$ & 0.968 \\
\hline$A G F I$ & $0.90 \leq A G F I \leq 1.00$ & $0.85 \leq A G F I \leq 0.90$ & 0.946 \\
\hline$R F I$ & $0.90<R F I<1.00$ & $0.85<R F I<0.90$ & 0.985 \\
\hline
\end{tabular}

When examining the above figure, self-efficacy and hope are seen to increase with increases in scores for the PMAs Test 7-11 Similarly, as the self-efficacy and hope rise, the students' levels of social emotional learning increase. The model fit values related to this are presented in detail in Table 6. When we look at the mediator role of self-efficacy and hope which is the main aim of the study; while the relationship between Primary Mental Abilities Test 7-11 and social-emotional learning was .27, it was .11 as a result of path analysis. In this case, self-efficacy and 
hope play a partial mediating role.

As can be understood from Table 6, our model well satisfies all the compliance measures.

\section{Discussion}

The analyses of the research have examined the PMAs Test 7-11, self-efficacy, emotional learning, and hope scores according to gender in the first stage. Although not significant in terms of the PMAs scores, a situation does exist in favor of female students when looking at the arithmetic averages. Meaningful results were obtained in favor of female students in terms of the variables of self-efficacy, emotional learning, and hope. Durualp (2014) reached the conclusion that girls' emotional learning is more meaningful in a gender study of sixth, seventh, and eighth graders. Akçalan (2016) also found girls' emotional learning to be higher in their studies. Britner and Pajares (2001) found that girls in secondary education have higher self-efficacy levels in the academic setting than boys, while boys are more successful at setting goals. A 4-year study by Heaven and Ciarrochi (2008) examined how students' levels of hope and self-esteem developed over the effects of gender and family lifestyles on these variables. As a result of their research, seventh-grade female students were determined to have higher levels of hope than the male students, but this decreased over time as 10th-grade girls had lower hopes levels than the boys.

One-way ANOVA testing has been conducted to determine whether the PMAs of students differ according to their levels of self-efficacy, emotional learning, and hope; a significant correlation has been found with respect to each of these three variables. This significance is found to favor highly skilled children according to post-hoc test results. Akarsu (2001) stated gifted children to be successful in achieving self-efficacy, social-emotional learning, and adapting to new situations. A study conducted by Mecek and Taşlidere (2015) concluded gifted children's mathematical achievements to be better than other students. Kolitch and Brody (1992), studying seventh- through 12-th grade students in the classroom, found gifted students to be able to comprehend mathematics much sooner than their peers. In a similar study, Poelzer and Feldhusen (1996) found gifted students to be more successful in physics, chemistry, and biology courses than other students. A study by Pajares (1996) was conducted on the academic self-efficacy of gifted and non-gifted students. The study investigated students' beliefs about their self-efficacy in mathematics. Research, in line with the obtained results, has emphasized students' self-efficacy beliefs to increase their success and this personal characteristic to be an important variable predicting academic success (Chemers, Hu, \& Garcia, 2001; Elias \& Loomis, 2002; Uyulgan \& Akkuzu, 2017). A positive relationship also has been found to exist between social-emotional learning and academic achievement. According to Zins, Bloodworth, Weissberg, and Walberg (2007) for example, providing students with social-emotional field training promotes self-awareness, social awareness, decision making by taking responsibility, adequate self-management, and relationship-management skills, as well as supporting students' academic achievement. According to Arslan and Akın (2013), social-emotional learning skills are very effective for students in school on things such as academic success, advancing social skills, developing problem-solving skills, motivating the learning process, gaining interest in reading, and actively participating in collaborative processes. Day, Hanson, Maltby, Proctor, and Wood (2010) found a positive relationship between students' hopes and future academic achievement in their 3-year longitudinal study. Curry, Synder, Cook, Ruby, and Rehm (1997) stated in their study that hope affects both athletic and non-athletic students' academic achievement and success in sports.

As a result of the path analysis for the third purpose of the study, the mediating role of the variables of hope and self-efficacy on the relationship between students' PMAs and social-emotional learning of the students was examined. At this point, the analyses that are the most important result of the study show that as scores for the PMAs Test 7-11 increase, hope and self-efficacy also increase. Similarly, social emotional learning increases in parallel with increases in hope and self-efficacy. Many studies are found showing self-efficacy to have a direct effect on performance and academic adjustment and a positive influence on one's capacities (Aydın, 2010; Carpenter, 2007; Sarıer, 2016). This study has shown individuals with high hope and self-efficacy to also have high social-emotional learning. Similarly, hope and self-efficacy act as partial mediators between PMAs and social-emotional learning. Feldman and Kubota's (2015) study found general hope to predict the areas of academic hope and academic self-efficacy. In addition, Ciarrochi, Heaven and Davies (2007) investigated in their study the effects of self-efficacy, hope, and positive loading styles on students' emotional status and future academic achievement as three distinctive features of positive thinking. As a result, hope was shown to lead to positive sentiments and high grades while adverse uploading styles lead to feelings of hostility and fear.

As a result, this study has attempted to evaluate the status of students who had taken the PMAs Test 7-11 as well as various scales according to their skill levels. It may be appropriate to The obtained findings have revealed that identifying students who need to be supported in this context by examining their levels of self-efficacy and hope using a more comprehensive program may be appropriate, as well as planning for students with high capability levels. As a result, continuing practices that will make gifted individuals feel valuable may be advisable. Future individual and group studies may be proposed within the 
context of educational and personal guidance services for supporting the self-efficacy prospects of students at different capability levels. Families should also be supported in order to support the work done in school. Parent seminars can be organized for sharing information on how children can contribute to their self-efficacy and learning processes according to their ability level. In addition, parental interviews can also be given in order to become more effective at supporting children's psychological processes.

This research is limited to the assessment of primary school students' ability levels and levels of social-emotional learning, self-efficacy, and hope. Because the study was not applied to students from different classes or grades, no generalization can be made about them. Different findings may be reached when designing various models in future studies. Using techniques such as interviewing and observation $\mathrm{s}$ in future qualitative research to be carried out within the scope of this subject can obtain more detailed results on the factors that predict the success of students at different skill levels.

\section{REFERENCES}

[1] Akarsu, F. (2001). Yetişemediğimiz çocuklar: Üstün yetenekli çocuklar ve sorunları [Children we do not catch: Gifted children and their problems]. Ankara: Eduser Yayınları.

[2] Akçaalan, M. (2016). Yaşam boyu öğrenme ile sosyal duygusal öğrenme arasındaki ilişkilerin çeşitli değişkenler açısından incelenmesi. (Yayımlanmamış Yüksek Lisans Tezi). Sakarya Üniversitesi, Eğitim Bilimleri Enstitüsü, Sakarya.

[3] Akın, A. (2015). Psikolojide kullanılan güncel ölçme araçları [Current measuring instruments used in psychology]. (Genişletilmiş 2. basım) Ankara: Nobel Akademik Yayıncilık.

[4] Arslan, S. ve Akın, A. (2013). Sosyal Duygusal Öğrenme Ölçeği: Geçerlik ve güvenirlik çalışması [Social Emotional Learning Scale: Validity and reliability study]. Sakarya Üniversitesi Eğitim Fakültesi Dergisi [The Journal of SAU Education Faculty], 25, 23-34.

[5] Arslan, Ş. (2016). İlkokula devam eden üstün yetenekli çocukların sosyal davranış özellikleri ile benlik algıları arasındaki ilişkinin incelenmesi (Bahçelievler ilçesi örneği). (Yayımlanmamış Yüksek Lisans Tezi). Marmara Üniversitesi, Eğitim Bilimleri Enstitüsü, İstanbul.

[6] Atılgan, H. (2005). Türkçeye uyarlanmış Temel Kabiliyetler Testi (TKT) 7-11'in yapı geçerliği [Construct validity of Basic Abilities Test 7-11 adapted to Turkish]. Türk Psikolojik Danışma ve Rehberlik Dergisi [Turkish Psychological Counseling and Guidance Journal], 3(24), 57-72.

[7] Atik, G. ve Kemer, G. (2009). Çocuklarda Umut Ölçeği’nin psikometrik özellikleri: Geçerlik ve güvenirlik çalışması
[Psychometric Properties of Children's Hope Scale: Validity and Reliability Study]. İlköğretim Online [Elementary Education Online], 8(2), 379-390.

[8] Aydın, F. (2010). Akademik başarının yordayıcısı olarak akademik güdülenme, öz yeterlilik ve sınav kaygısı. (Yayımlanmamış yüksek lisans tezi). Hacettepe Üniversitesi, Ankara.

[9] Britner, S.L. ve Pajares, F. (2001). Self-efficacy beliefs, motivation, race, and gender in middle school science. Journal of Women and Minorities in Science and Engineering, 7(4), 271-285.

[10] Carpenter, S. L. (2007). A comparison of the relationships of students' self-efficacy, goal orientation, and achievement across grade levels: a meta-analysis. (Unpublished of master thesis). Simon Fraser University, Canada.

[11] Chemers, M. M., Hu, L. \& Garcia, B. F. (2001). Academic self-efficacy and first year college student performance and adjustment. Journal of Educational Psychology, 93(1), 55-64.

[12] Ciarrochi, J., Heaven, P., \& Davies, F. (2007). The impact of hope, self-esteem, and attributional style on adolescents' school grades and emotional well-being: A longitudinal study. Journal of Research in Personality,41(6), 1161-1178.

[13] Curry, L. A., Synder, C. R., Cook, D., Ruby, B. C., \& Rehm, M. (1997). Role of hope in academic and sport achievement. Journal of Personality and Social Psychology, 73 (6), 1257-1267.

[14] Day, L., Hanson, K., Maltby, J., Proctor, C., \& Wood, A. (2010). Hope uniquely predicts objective academic achievement above intelligence, personality, and previous academic achievement. Journal of Research in Personality, 44 (4), 550-553.

[15] Durlak, J. A., Weissberg, R. P., Dymnick, A. B., Taylor, R. D., \& Schellinger, K. B. (2011). The impact of enhancing students' social and emotional learning: A meta-analysis of school- based universal interventions. Child Development, 82(1), 405-432.

[16] Durualp, E. (2014). Ergenlerin sosyal duygusal öğrenme becerilerinin cinsiyet ve sinıfa göre incelenmesi [An investigation of adolescent' social emotional learning skills in terms of gender and grade]. Uluslararas1 Sosyal Bilimler Dergisi [International Journal of Social Science], 26, 13-25.

[17] Elias, S., \& Loomis, R. (2002). Utilizing need for cognition and perceived self-efficacy to predict academic performance. Journal of Applied Social Psychology, 32(8), 1687- 1702.

[18] Feldman, D., \& Kubota, M. 2015). Hope, self-efficacy, optimism, and academic achievement: Distinguishing constructs and levels of specificity in predicting college grade-point average, Learning and Individual Differences, 37, 210-216.

[19] Ford, M. A. (1989). Students' perceptions of affective issues impacting the social emotional development and school performance of gifted/talented youngsters, Roeper Review, 11(3), 131-134.

[20] Gardner, H. (1987). The theory of multiple intelligences. Annals of Dyslexia, 37(1), 19-35.

[21] Goleman, D. (1998). Duygusal zekâ neden IQ'dan daha 
önemlidir? [Why emotional intelligence is more important than IQ?]. (Çev. B. Seçkin Yüksel). İstanbul: Varlık.

[22] Graziano, P. A., Reavis, R. D., Keane, S. P., \& Calkins, S. D. (2007). The role of emotion regulation in the children's early academic success. Journal of School Psychology, 45, 3-19.

[23] Gresham, F. M., \& Elliott, S. N. (1990). Social skills rating system (SSRS). Circle Pines, MN: American Guidance Service.

[24] Guerrero, L. K., \& Jones, S. M. (2003). Differences in one's own and one's partner's perceptions of social skills as a function of attachment style. Communication Quarterly, 51(3), 277-295.

[25] Heaven, P. \& Ciarrochi, J. (2008). Parental styles, gender and the development of hope and self-esteem. European Journal of Personality, 22 (8), 707-724.

[26] Kolitch, E. R., \& Brody, L. E. (1992). Mathematics acceleration of highly talented students: An evaluation. Gifted Child Quarterly, 36, 78-86.

[27] Marlowe, H. A. (1986). Social intelligence: Evidence for multidimensionality and construct independence. Journal of Educational Psychology, 78(1), 52-58.

[28] Marquez, P. G., Martin, R. P., \& Brackett, M. A. (2006). Relating emotional intelligence to social competence and academic achievement in high school students. Psicothema, $18,118-123$.

[29] Mecek, S., \& Taşlıdere, E. (2015). Üstün zekâlı/yetenekli öğrencilerin matematik ve fizik akademik başarılarının çeşitli değişkenler açısından incelenmesi [Investigation of gifted students mathematics and physics achievements in terms of different variables]. Pegem Eğitim ve Öğretim Dergisi [Pegem Journal of Education and Instruction], 5(5), 733-746. http://dx.doi.org/10.14527/pegegog.2015.040.

[30] Moulden, H. M. and Marshall, W. L. (2005). Hope in the treatment of sexual offenders: The potential application of hope theory. Psychology, Crime \& Law, 11(3), 329- 342.

[31] O’Connor, R. M., \& Litte, I. S. (2003). Revisiting the predictive validity of emotional intelligence: self-report versus ability based measures. Personality and Individual Differences, 35, 1893-1902.

[32] Pajares, F. (1996). Self-efficacy beliefs and mathematical problem-solving of gifted students. Contemporary Educational Psychology 21, 325-344.

[33] Parker, J. D. A., Summerfeldt, L. J., Hogan, M. J., \& Majeski, S. A. (2004). Emotional intelligence and academic success: examining the transition from high school to university. Personality and Individual Differences, 36, 163-172.

[34] Poelzer, G.H. \& Feldhusen, J.F. (1996). An empirical study of the achievement of international baccalaureate students in biology, chemistry, and physics--in Alberta. Journal of Secondary Gifted Education, 8-1

[35] Renzulli, S. J. (1986). The three-ring conception of giftedness: a developmental model for promoting creative productivity. Retrieved from http://gifted.uconn.edu/wp content/uploads/sites/961/2015/01/TheThreeRing_Concepti on_of_Giftedness.pdf.

[36] Salanova, M., Martínez, I. M., and Lorens, S. (2012).
Success breeds success, especially when self-efficacy is related with a cousality internal attribution. Estudios de Psicologia, 33, 151-165.

[37] Sarıer, Y. (2016). Türkiye'de Öğrencilerin Akademik Başarısını Etkileyen Faktörler: Bir Meta-analiz Çalışması [The Factors That Affects Students' Academic Achievement in Turkey: A Meta-Analysis Study]. Hacettepe Üniversitesi Eğitim Fakültesi Dergisi [Hacettepe University Journal of Education], 31(3), 609-627.

[38] Silverman, L. K. (1993). Social development, leadership, and gender issues. In L. K. Silverman (Ed.), Counseling the gifted and talented, (pp. 291-327). Denver, CO: Love Publishing.

[39] Tarhan, S. ve Bacanlı, H. (2016). İlkokuldan üniversiteye umut kavramının tanımlanması üzerine nitel bir çalışma [A qualitative study on defining the concept of hope from primary school to university]. Eğitimde Nitel Araștırmalar Dergisi [Journal of Qualitative Research in Education], 4(2), 86-113.

[40] Telef, B. B. ve Karaca, R. (2012). Cocuklar İçin Öz-Yeterlik Ölçeği: Geçerlik ve güvenirlik çalışması [The Self-Efficacy Scale For Children; A validity and reliability study]. Buca Eğitim Fakültesi Dergisi [Buca Journal of Faculty of Education], 32, 169-187.

[41] Uyulgan, M.A. ve Akkuzu,N. (2017). Ortaöğretim öğrencilerinin akademik başarılarını yordayan kişisel faktörler üzerine bir araştırma [A research on personal factors predicting academic achievement of secondary school students]. Bartın Üniversitesi Eğitim Fakültesi Dergisi [Bartın University Journal of Faculty of Education], $6(3), 1211-1226$.

[42] Webb, J. T. (1994). Nurturing social emotional development of gifted children. ERIC Digest E527. Retrieved from https://files.eric.ed.gov/fulltext/ED372554.pdf.

[43] Yavuzer, H. (2011). Çocuk psikolojisi [Child psychology] (3. Bask1). İstanbul: Remzi Kitabevi.

[44] Yörükoğlu, A. (1983). Çocuk ruh sağlığ1 [Child psychological health]. Ankara: Türkiye İş Bankası Kültür Yayınları.

[45] Zins, J. E., Bloodworth, M. R., Weissberg, R. P., \& Walberg, H. J. (2004). The foundation of social and emotional learning. In J. E. Zins, R. P. Weissberg, M. C. Wang, \& H. J. Walberg (Eds.), Building academic success on social and emotional learning: What does the research say? (pp. 3-22). New York: Teachers College Press.

[46] Zins, J. E., Bloodworth, M. R., Weissberg, R. P. \& Walberg, H. J. (2007). The scientific base linking social and emotional learning to school success. Journal of Educational and Psychological Consultation, 17(2), 191-210. 